
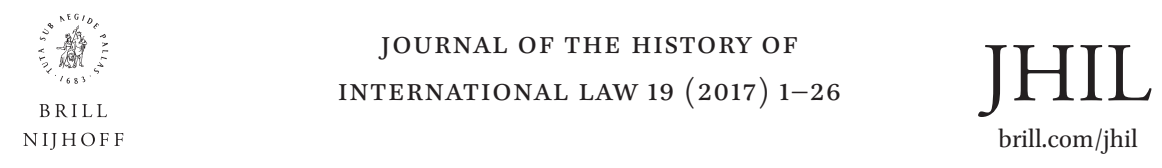

$-1 \mathrm{X}$

\title{
Breach of Treaties in the Ancient Near East
}

Gábor Sulyok

Senior research fellow, Hungarian Academy of Sciences Centre for

Social Sciences, Institute for Legal Studies, Budapest, Hungary

Abstract

The history of the breach of treaties can be traced back to the ancient Near East. The

relative abundance and diversity of contemporary sources attest that the breaking of treaty obligations must have been a rather persistent problem, and that such occurrences were regarded as events of utmost importance throughout the Bronze and Iron Ages. The present study strives to demonstrate how peoples of old may have perceived

Keywords

ancient Near East - breach - treaty

Treaties have shaped the behaviour of states since the dawn of history. 1

1 The present study does not intend to prove or disprove the existence of international law in ancient times. However, recourse to modern international legal terminology cannot be avoided; technical terms in the study are to be interpreted with the foregoing in mind. The spelling of personal, divine and geographical names may display slight variations in the lit- 
Near East, where parties of equal or unequal status routinely concluded agreements, parity and non-parity/vassal treaties, in an effort to achieve a certain degree of orderliness and predictability in a complex and challenging environment. ${ }^{2}$ These early treaties had two essential constituents: the treaty bond/stipulations and the oath by the gods. This latter constituent bears particular significance for the purposes of our investigation. The promissory oath sworn by the gods and goddesses of either or both parties, among others, expressed consent to be bound by the treaty, brought about the entry into force of the treaty, and placed the treaty under divine supervision. The specific methods of treaty-making changed with region, period and treaty type, but in general terms, it may be stated that treaty relations were established by a conjunction of parallel and 'self-standing "legal act[s]".3 Treaty compliance was predominantly, albeit not exclusively, guaranteed by negative inducements in the form of curses. Terrifying conditional maledictions were devised to deter parties from breaking their obligations and to punish any kind of transgression by holding out the prospect of demise, destruction, pain and suffering. The anticipated dire consequences, let alone the pleasing but less prevalent

throughout the consulted translation of the Old Testament: 'Lord'. Names of political entities are used in a simplified form and lack references to periodisation (Egypt = Egyptian New Kingdom, Hittite kingdom/Hatti = Hittite Middle or New Kingdom [as appropriate], Assyria $=$ Middle Assyrian Empire, [Kassite] Babylonia $=$ Karduniash $)$. Further information on the entities featuring in the present study can be found in Trevor Bryce, The Routledge Handbook of the Peoples and Places of Ancient Western Asia: The Near East from the Early Bronze Age to the Fall of the Persian Empire (London: Routledge 2009). The chronology of the ancient Near East is uncertain and debated. The dates are approximate and follow the short/low chronology.

2 For more details see Amnon Altman, Tracing the Earliest Recorded Concepts of International Law: The Ancient Near East (2500-330 ВСE) (Leiden: Martinus Nijhoff 2012), 20-22, 34-38, 67-78, 111-142, 189-199; Michael L. Barré, 'Treaties in the ANE', in David N. Freedman (ed.), The Anchor Bible Dictionary, vol. 6 (New York: Doubleday 1992), 653-656; David J. Bederman, International Law in Antiquity (Cambridge: Cambridge University Press 2001), 137-154; Elena Devecchi, 'Treaties, ancient Near East', in Roger S. Bagnall et al. (eds.), The Encyclopedia of Ancient History, vol. 12 (Malden: Wiley-Blackwell 2013), 6836-6837; Dennis J. McCarthy, Treaty and Covenant: A Study in Form in the Ancient Oriental Documents and in the Old Testament (Rome: Biblical Institute Press, New edition 1978); Gábor Sulyok, 'Treaties, Origin', in Rüdiger Wolfrum (ed.), The Max Planck Encyclopedia of Public International Law (Oxford University Press 2015), available at: http://opil.ouplaw.com/home/epil; Raymond Westbrook (ed.), A History of Ancient Near Eastern Law, vols. 1-2 (Leiden: Brill 2003), 244-249, 747-750, 759-764, 1054-1059 (contributions by Jerrold Cooper, Jesper Eidem, Gary Beckman and Simo Parpola).

3 Robert Kolb, The Law of Treaties: An Introduction (Cheltenham: Edward Elgar 2016), 2, 13-15. 
treaty guarantees (e.g., blessings), could seldom withhold parties from acting $1 \mathrm{X}$ in contravention of an agreement when such course of action better served their interests. Hence the history of the breach of treaties is inseparable from the history of treaties themselves. ${ }^{4}$

For example, the treaty of Eanatum of Lagash and Enakale of Umma (ca $25^{\text {th }}$ century BCE), one of the earliest known agreements, was breached shortly after its conclusion. This famous treaty, whose detailed narrative was preserved on the Stele of the Vultures, sought to settle a prolonged territorial dispute and terminate a bitter conflict between two neighbouring Sumerian city-states. ${ }^{5}$ Later records show that respect for the treaty did not last long. Enanatum I and Enmetena/Entemena, the two successors of Eanatum's, were already compelled to confront their neighbour in the wake of a series of transgressions. Urlumma, son of Enakale, failed to repay his debt, diverted water from the boundary dikes, destroyed the monuments and chapels along the border, hired foreign troops and invaded the disputed territory. Hostilities flared up again. Urlumma suffered a humiliating defeat, and although escaped with his life, ultimately met his fate in his own capital. Leadership in Umma was seized by a like-minded ruler, Il. Following the policy of his predecessor, he diverted water from the boundary dikes, failed to fully repay his debt and laid unjustified territorial claims. However, his ambitions were also checked by the gods. ${ }^{6}$ Lagash, the injured party, emerged victorious - for now.

This particular story reached us on royal inscriptions. These propagandistic and narrowly focused ancient texts may prove helpful in the reconstruction of past events, but on account of their specific purposes and properties, have often limited use in the exposition of more intricate details. Fortunately, the breach of treaties also featured in a range of other contemporary sources, including historical prologues of treaties, diplomatic correspondence, annals and chronicles, literary works, religious texts and prayers as well as miscellaneous writings that escape easy classification. The relative abundance and diversity of sources attest that the breaking of treaty obligations must have been a rather persistent problem, and that such occurrences, for all their apparent frequency, were regarded as events of utmost importance throughout the Bronze and Iron Ages. ${ }^{7}$ But the range of contemporary sources, if treated with

4 Sulyok, 'Treaties, Origin' 2015 (n. 2), para. 36.

5 Jerrold S. Cooper, Reconstructing History from Ancient Inscriptions: The Lagash-Umma Border Conflict (Malibu: Undena 1983).

6 Douglas R. Frayne, The Royal Inscriptions of Mesopotamia: Early Periods, vol. 1: Presargonic 
an adequate amount of criticism, reveals so much more. The present study strives to demonstrate how peoples of the ancient Near East may have perceived and reacted to the breach of treaties on the basis of selected writings that provide, beyond the exposition of actual or alleged facts, a deeper insight into the psychological and procedural aspects of the subject. The selection is designed to include writings from different regions, periods and literary genres to facilitate the identification of recurring motifs and the formulation of a few general observations.

\section{The Legend of Etana}

The traditional tale of a king who embarked on a dangerous journey to the heavens on the back of an eagle may admittedly not present itself as an evident point of departure, but the legend of Etana is absolutely indispensable for a better understanding of our subject. Indeed, the usefulness of ancient literary works in the study of the history of international law has long been recognized. ${ }^{8}$ The legend of Etana reached us in three fragmentary versions-an Old Babylonian, a Middle Assyrian and a Standard/Neo-Assyrian. Nevertheless, the story must be considerably older than the surviving copies; cylinder seals from the late third millennium BCE display artistic depictions of central motifs of the tale. ${ }^{9}$ This remarkable composition recounts the adventures of Etana, king of Kish, a once mighty and influential city-state located in the heart of Mesopotamia. Etana is a quasi-historical figure, and his name appears on the so-called Sumerian King List: 'After the flood had swept over, when kingship had come down from heaven, kingship (was) at Kiš. [...] Etana the shepherd, the one who went up to heaven, who put all countries in order, was king; he reigned 1,500 years.' ${ }^{10}$

Etana was, according to the story, personally appointed by the gods as ruler after kingship descended from heaven again following the deluge. Though he

8 Péter Kovács, 'Relativities in Unilateralism and Bilateralism of the International Law of Antiquity', Journal of the History of International Law 6(2) (2004), 173-186, 186.

9 Tradition attributed the authorship of the legend to a Sumerian demi-sage, Lu-Nanna. Stephanie Dalley, Myths from Mesopotamia: Creation, the Flood, Gilgamesh, and Others (Oxford: Oxford University Press, Revised edition 200o), 189. See also James V. Kinnier Wilson, The Legend of Etana: A New Edition (Warminster: Aris \& Phillips 1985).

10 Jean-Jacques Glassner, Mesopotamian Chronicles (Atlanta: Society of Biblical Literature 2004), 121. See also Thorkild Jacobsen, The Sumerian King List (Chicago: The University of Chicago Press 1939). 
proved to be a worthy and pious king, he and his wife had not been blessed with a child yet; therefore, the securing of the royal line emerged as a matter of concern. Keen to remedy the situation, Etana boldly ascended to the heavenly realm of the gods on the back of an eagle to obtain the plant of birth from Ishtar, the goddess of war, love and fertility. The fragmentary condition of the surviving copies leaves the dénouement of the plot shrouded in obscurity. ${ }^{11}$ Nowadays, the majority of scholarly opinion favours the view that the endeavour resulted in success, the desperate king obtained the magical plant and his wife gave birth to a child. The Sumerian King List also supports this reading: 'Balihh, son of Etana, reigned 400 years'.12 The legend may, in fact, have been considerably longer. The possible continuation of the story, which would complement the main plot with entirely new elements, including the unconscious slaying of Etana by Balih, is being actively explored and debated. ${ }^{13}$

Knowledge of the breach of treaties may be specifically extracted from a lengthy animal tale, the fable of the eagle and the serpent, which forms an integral part of the legend, though it only has secondary relevance to the main plot. This fable sheds light on the antecedents of the unlikely acquaintance and friendship of the king and the bird. The chief characters are the eagle and the serpent, who once made up their minds to conclude a treaty of friendship and swore an oath before Shamash, the god of law and justice (Sumerian: Utu), in accordance with contemporary practices. Numerous curses guaranteed treaty compliance: for example, if either party broke its obligations, it would be delivered into the hands of the smiter, the mountain would keep its pass far away from it, the prowling weapon would make straight for it and the snares on which the oath to Shamash was sworn would overturn and ensnare it. ${ }^{14}$

Having sworn the oath, the new friends hunted in turns, ${ }^{15}$ shared their prey and nurtured their offspring together. When the nestlings of the eagle had grown up and gained strength, the bird conceived an evil plan-it decided to devour the young of the serpent. It disclosed its scheme to its nestlings, one of whom, an 'especially wise' one, strove to persuade its father not to transgress

\footnotetext{
11 Dalley, Myths from Mesopotamia 2000 (n. 9), 190-200.

12 Glassner, Mesopotamian Chronicles 2004 (n. 10), 121.

13 James Kinnier Wilson, Studia Etanaica: New Texts and Discussions (Münster: Ugarit-Verlag 2007).

14 Dalley, Myths from Mesopotamia 2000 (n. 9), 191-192.

15 In the early versions, we only find the serpent hunting. Benjamin R. Foster, 'Akkadian Literature', in Carl S. Ehrlich (ed.), From an Antique Land: An Introduction to Ancient Near Eastern Literature (Lanham: Rowman \& Littlefield 2009), 172. See also 'Etana' (Ephraim A. Speiser trans.), in James B. Pritchard (ed.), Ancient Near Eastern Texts Relating to the Old Testament (Princeton: Princeton University Press, Third edition 1969), 115.
} 
the treaty by reminding it of the possible consequences. Undeterred by the prudent warning and the prospect of divine punishment, the eagle ruthlessly fulfilled its plan as the opportunity arose. ${ }^{16}$ The serpent was shocked to witness the treachery of the eagle upon its arrival home. Horrified by what had transpired, it turned to the divine witness and guarantor of the treaty:

The serpent lay down and wept, Its tears flowed before Shamash.

'I trusted in you, Shamash the warrior,

And I was helpful (?) to the eagle who lives on the branches. [...]

It came down and ate my young ones!

You know the wrong which it has done me, Shamash!

Truly, O Shamash, your net is as wide as earth,

Your snare is as broad as the sky!

The eagle should not escape from your net,

As criminal as Anzu, who wronged his comrade.17

Shamash heard the plea of the serpent and resolved to punish the eagle. He directed the reptile to hide inside a fallen animal and ambush the bird. The voracious eagle was expected to land and feast from the flesh. The snake was then to seize it, cut its wings, feather and pinion, pluck and throw it into a deep pit and leave it to its fate. Lest the serpent bring the divine punishment upon himself, it faithfully executed the instructions; the eagle begged for mercy to no avail. Shamash likewise remained adamant for a long time and reproached the bird for what it had committed. He pronounced that the wicked eagle had grieved his heart and had done 'an unforgivable deed, an abomination to the gods.' ${ }^{18}$ The retribution features highly sophisticated symbolism. It has been pointed out that on account of its transgression " $[t]$ he eagle finds himself removed to the polar opposite of his natural position, down into the pit. The breaking of the compact, itself a reversal of Shamash's rule of law, has resulted

\footnotetext{
16 Dalley, Myths from Mesopotamia 2000 (n. 9), 192-193.

17 Ibid., 193. Anzu/Zu was a Sumerian and Akkadian mythological being, a storm-bird that possessed the attributes of both monsters and deities. In another story, Anzu stole the Tablet of Destinies, a tablet granting absolute power over the universe, which the gods could only retrieve after considerable effort.
}

18 Ibid., 193-195. 
in a complete reversal of the natural relations between eagles and snakes. ${ }^{19} \quad 1 X$ The deity at last told the eagle that he would eventually send a man to release $\quad 2$ it from its prison. The storylines of the king and the bird meet at this critical 3 stage. Following the instructions of Shamash, Etana sought out and rescued 4 the eagle that redeemed itself, in a way, by helping the king to gain possession $\quad 5$ of the plant of birth. ${ }^{20}$

The Legend of Etana is a most valuable source indeed. This popular literary composition may originally have served to strengthen dynastic legitimacy, but the embedded animal tale does not seem to be politically motivated in any way. The fable of the eagle and the serpent, which presents the breach of a fictional treaty from both perspectives, thus had the potential to transmit an important moral lesson through countless generations in an easily comprehensible manner: the breach of a treaty is a heinous offence against both the other party and the god(s) of the oath, the transgressor has to be held in contempt, the punishment is harsh and inescapable and forgiveness is extremely hard to obtain.

The Hittite kingdom has furnished us with rather indignant and propagandistic documents, colloquially labelled 'indictments', which allow a glimpse of the dealings of Hittite kings with vassals who failed to abide by their treaty obligations: the Indictment of Madduwatta and the Indictment of Mita. The former is a fragmentary draft of a lengthy text addressed by a king to a vassal that relates the transgressions committed by the recipient in the west before and during the reign of the author. The latter, on the other hand, is a much shorter and broken text addressed by a king to third parties that relates the transgressions committed by another vassal in the east. This text has been characterized as a 'curious hybrid', since it appears to have been attached to the front of a treaty of the king with the elders of several small communities. ${ }^{21}$

19 Geoffrey S. Kirk, Myth: Its Meaning and Functions in Ancient and Other Cultures (London/ Berkeley/Los Angeles: Cambridge University Press/University of California Press, Reprint 1975), 129. 160. 
Nowadays, both documents are mostly dated to the reign of Arnuwanda I (ca early 14 th century BCE). ${ }^{22}$

Madduwatta is portrayed as an exceptionally notorious and ungrateful troublemaker in the 'indictment'. His disreputable career began after he and his family, servants and troops had been chased away from his land by Attarissiya, ruler of Ahhiyawa ( Mycenaean world?). He fled for his life to the 'father'actually the father-in-law and predecessor-of the author, Tudhaliya I/II (ca early 14th century BCE), who afforded him protection, weapons and means of sustenance. The text bluntly reminds him of his misery: 'And the father of My Majesty saved you from the sword of Attarissiya. [...] Otherwise, dogs would have devoured you from hunger.' 23 The parties also concluded a non-parity treaty, by which the fugitive became a vassal of the Hittite king. This treaty has not been found yet, ${ }^{24}$ but the text repeats many elements thereof, including the bestowal of land upon the inferior party, the obligation to guard and to protect that land, the prohibition to occupy additional lands, the provision of offensive and defensive military assistance against the enemy, the reporting of hostile matters and talk, the reporting of slanderous talk against the king or the princes, the prohibition to freely send or receive envoys, the prohibition to freely open hostilities and the seizure and extradition of fugitives. The agreement specifically designated Kupanta-Kurunta, ruler of Arzawa, as an enemy and prohibited diplomatic contacts with Attarissiya, ruler of Ahhiyawa. ${ }^{25}$ These provisions ranked among the usual elements of non-parity treaties. ${ }^{26}$

Madduwatta transgressed practically every obligation he had sworn to fulfil. The moment he took over his allotted land, he mobilized his troops and attacked Kupanta-Kurunta. However, the Arzawan campaign was a catastrophe: the attacker suffered a humiliating defeat and escaped 'naked', his army was destroyed and his family and possessions were captured. The Hittite king had to deploy chariots and infantry, risking the lives of the distinguished nobles in command, to remedy the situation. Kupanta-Kurunta was forced to flee leaving his family and possessions behind, the prisoners were released and the vassal was reinstalled. Then Attarissiya returned to eliminate at last his long-standing adversary. Madduwatta displayed a surprisingly low

E.g. Trevor Bryce, The Kingdom of the Hittites (Oxford: Oxford University Press, New edition 2005), 129, 143; Horst Klengel, Geschichte des hethitischen Reiches (Leiden: Brill 1998), 108-109, 118. See also Beckman, Hittite Diplomatic Texts 1999 (n. 21), 153.

Beckman, Hittite Diplomatic Texts 1999 (n. 21), 154.

Elena Devecchi, 'Missing Treaties of the Hittites', Kaskal 12 (2015), 155-182, 161, 178.

Beckman, Hittite Diplomatic Texts 1999 (n. 21), 154-155.

Sulyok, 'Treaties, Origin' 2015 (n. 2), para. 22. 
fighting spirit this time, having broken ranks and done nothing to resist the $1 \mathrm{X}$ attack. Hittite military units under the command of Kisnapili had to come to the rescue again, which repelled the enemy and reinstalled the vassal once 2 more. Madduwatta was clearly not an appreciative kind though. Later, when the city of Dalawa took up arms, he ostensibly decided to fulfil his obligations, and suggested that Kisnapili launch simultaneous attacks against Dalawa and Hinduwa. But Madduwatta never really meant to accomplish his part of the plan. He betrayed the movements of the Hittite troops to the enemy, who set up an ambush, killed the commanders and routed the soldiers - much to the satisfaction of the scheming vassal. He caused further trouble by persuading the elders of Dalawa to swear an oath and pay tribute to him. ${ }^{27}$

His series of transgressions continued as he retained peaceful relations with Kupanta-Kurunta, and even offered him his daughter in marriage, at a time when there was animosity between his suzerain and the other ruler. The king strongly protested against his conduct. Madduwatta was, of course, ready with an explanation: the marriage offer was merely a subterfuge to draw near and dispose of Kupanta-Kurunta. The king was not entirely convinced of his sincerity, but allowed him to proceed at his discretion: 'Do as seems right to you'.28

The territorial ambitions of the vassal were as boundless as his unscrupulousness. Notwithstanding that his suzerain had bestowed upon him additional pieces of land, he conducted numerous military expeditions utterly incompatible with his commitments in an attempt to extend the borders of his territory. Madduwatta either attacked other lands without permission from the king, failed to properly transfer his sanctioned conquests to the king, or audaciously occupied lands that actually belonged to the king himself. He strove to remain in possession of his unlawful conquests at any cost; he only relinquished territories to the king when it was absolutely necessary. Madduwatta was similarly reluctant to extradite fugitives and persistently evaded demands to that effect. The huntsman of the king also fled to him, but he refused to harbour him. When a royal envoy found the huntsman in his court after all, he replied that the fugitive belonged to the household of his son. ${ }^{29}$ The text reflects the level of frustration his behaviour may have caused: '[And] we write to you [...] about this matter, but you do [not] subsequently [present] a defense to us in the matter. [And] you [write] about some other matters. You always write us back about other matters. ${ }^{30}$

27 Beckman, Hittite Diplomatic Texts 1999 (n. 21), 156-157. 37

$28 \quad$ Ibid., 157 . 38

$29 \quad$ Ibid., 157-160. $\quad 39$

$30 \quad$ Ibid., $158 . \quad 40 X$ 
The treacherous vassal at one point provoked the chieftains and elders of the land of Pitassa to attack the kingdom, and refused to provide military assistance against the enemy—he 'hid his eyes' instead. Madduwatta, along with his former adversary, Attarissiya and the ruler of Piggaya, also regularly raided the land of Alashiya ( Cyprus?), in spite of the fact that the territory belonged to the king. He was called to account, admitted the raids, but claimed to be innocent. He shifted the responsibility to the successive kings: 'But the father of His Majesty [had] never [informed] me, [nor] had His Majesty ever informed [me] to the effect: "The land of Alashiya is mine-recognize it as such!'”31 The 'indictment' may have recounted more offences and provided more details; the colophon shows that the available text only forms the first tablet of the document. ${ }^{32}$

Madduwatta appears to have been treated with incredible forbearance by his suzerains. His ultimate fate is unknown, but if the text contains at least a grain of truth, his repeated transgressions mostly prompted protests and reproaches. Nevertheless, the supposed absence of more severe measures should arguably not be mistaken for weakness on the part of Tudhaliya and Arnuwanda. Their attention was at that time focused on other parts and problems of the realm. Hence this surprisingly lenient attitude may have been a sign of a pragmatic policy in the west or a tacit support of the actions of their vassal. ${ }^{33}$ The Indictment of Mita, on the contrary, reveals that the author was not in the slightest forgiving towards another transgressor in the east, uncomfortably close to a rival great power, Mitanni. ${ }^{34}$

Mita of Pahhuwa was likewise a vassal of the Hittite king, evidently bound to him by a missing non-parity treaty. ${ }^{35}$ The 'indictment' repeats some of the provisions of this treaty, and the fragmentary text implies that it probably contained the usual elements of such treaties. Mita allegedly broke his obligations on a number of occasions, ' $[\mathrm{h}] \mathrm{e}$ has transgressed all of the matters which had been placed under oath', ${ }^{36}$ but the list of his sins is still considerably shorter than that of Madduwatta. For example, he married the daughter of an enemy

$31 \quad$ Ibid., $158-160$.

32 The missing parts of the document may also have contained an appeal to the gods. Altman, Tracing the Earliest Recorded Concepts 2012 (n. 2), 6o, n. 41.

33 Bryce, The Kingdom of the Hittites 2005 (n. 22), 136-138. The lenient attitude of the successive kings may also be explained by their relative helplessness. Klengel, Geschichte des hethitischen Reiches 1998 (n. 22), 122.

34 Bryce, The Kingdom of the Hittites 2005 (n. 22), 144.

35 Devecchi, 'Missing Treaties' 2015 (n. 24), 177-178.

36 Beckman, Hittite Diplomatic Texts 1999 (n. 21), 162. 
of the king, harboured fugitives and allowed them to flee elsewhere and failed $1 \mathrm{X}$ to relinquish cities that belonged to the king. The text makes mention of some 2 kind of fighting, as well. ${ }^{37}$ Here the suzerain retaliated without hesitation. $\mathrm{He}$ summoned the dignitaries of several small communities in the region and presented the details of the transgressions. He peremptorily demanded the extradition of the transgressor and his family, servants and possessions from the men of Pahhuwa. He also demanded the relinquishment of his cities, the extradition of fugitives, the transfer of certain goods and the fulfilment of miscellaneous other obligations. Everyone and everything had to be handed over exactly as instructed, not even 'a strand of wool' could be withheld. The small communities were to oversee the conduct of the men of Pahhuwa until the army arrives, and to attack them immediately if they experienced disloyalty or disobedience. Failure to execute this command meant that the king would destroy the defaulting party before he turned against Pahhuwa. ${ }^{38}$ The remainder of the story is unknown, but the reaction of the king looks unpromising for his vassal.

The Hittite 'indictments' tend to reveal little to the casual reader other than a great deal of bias and frustration, contempt for the transgressors and detailed accounts of their transgressions. But there is much to learn from these intriguing texts. They present the perspective of a party who keeps the behaviour of his partners under close scrutiny, meticulously records suspicious activities and strongly protests against any form of misconduct. The texts also show that his reactions are not necessarily uniform: he tolerates the perfidy of one transgressor, but chooses to severely punish the other. Hence his attitude is primarily determined by considerations of power and politics rather than his respect for the gods of the oath, at least in the light of our fragmentary sources.

Hittite kings were also not hesitant to break their obligations when more important considerations outweighed the benefits of treaty compliance, as shown by a set of famous religious texts from the second half of the second millennium ВСE. The reign of Suppiluliuma I (ca 1344-1322 BCE) brought dynamic territorial expansion and significant military achievements for the Hittite kingdom. However, a most extraordinary episode of ancient history began to unfold during the siege of Carchemish/Karkamish. The king received a letter from the

$\begin{array}{ll}37 & \text { Ibid., 161-162 } \\ 38 & \text { Ibid., } 162-164\end{array}$


widow of the pharaoh of Egypt in which she asked for a Hittite prince for a husband: 'My husband died. A son I have not. But to thee, they say, the sons are many. If thou wouldst give me one son of thine, he would become my husband. Never shall I pick out a servant of mine and make him my husband!'39

The identities of the sender and her late husband have long been disputed, but indications are that the letter may have come from Ankhesenamun, the young widow of Tutankhamun (ca 1333-1323 BCE). Suppiluliuma received the request, which was at complete odds with traditional Egyptian practices relating to dynastic marriages, ${ }^{40}$ with utmost astonishment and serious misgivings. He called his nobles to council and gave voice to his ambivalent feelings: 'Such a thing has never happened to me in my whole life!'41 Having been a highly ambitious politician and strategist, the king obviously did not want to miss the historic opportunity. He dispatched his chamberlain to the Egyptian court to ascertain the seriousness of the request in person. Only when the queen resentfully reaffirmed her intention to get married in a letter, and it was eloquently underscored by the Egyptian envoy, did the 'kindhearted' king decide to send her one of his sons, Zannanza. The prince never reached his destination; he was probably assassinated along the way. ${ }^{42}$

Suppiluliuma immediately laid the blame for the murder of his son upon the Egyptians. The hastily enthroned next pharaoh, the elderly Ay (ca 13231319 ВСE), admitted the demise of the prince in a matter-of-fact tone, but denied any responsibility for the outrageous incident: he claimed to be innocent and hoped to prevent retaliation by the Hittites. ${ }^{43}$ His attempt to maintain relatively normal relations was doomed to failure. Driven by his anger, Suppiluliuma launched a punitive campaign against Egyptian territories that was only terminated by a devastating epidemic carried and spread by Egyptian prisoners of war. Even the Hittite king himself fell victim to the disease, which remains to be identified, but is mostly believed to have been either plague or

39 Hans G. Güterbock, 'The Deeds of Suppiluliuma as Told by His Son, Mursili II (Continued), Journal of Cuneiform Studies 10(3) (1956), 75-98, 94.

40 Alan R. Schulman, 'Diplomatic Marriage in the Egyptian New Kingdom', Journal of Near Eastern Studies 38(3) (1979), 177-193.

41 Güterbock, 'The Deeds of Suppiluliuma' 1956 (n. 39), 95.

42 Ibid., 95-98; Hans G. Güterbock, 'The Deeds of Suppiluliuma as Told by His Son, Mursili II', Journal of Cuneiform Studies 10(4) (1956), 107-130, 107-108.

43 William J. Murnane, The Road to Kadesh: A Historical Interpretation of the Battle Reliefs of King Sety I at Karnak (Chicago: The Oriental Institute of the University of Chicago, Second revised edition 1990), 25-28. 
tularaemia. His son and first successor, Arnuwanda II (ca 1322-1321 BCE), suf$1 \mathrm{X}$ fered a similar fate. ${ }^{44}$

The epidemic raged unchecked and also decimated the population during the reign of another son and second successor of Suppiluliuma, Mursili II (ca 1321-1295 BCE). The new king struggled to find the reasons and remedy for the calamity. His 'Second' Plague Prayer describes that he believed the pestilence to be a manifestation of divine wrath and made an inquiry through an oracle. The oracle revealed the existence of two old tablets. The first tablet concerned the ritual of the Mala river, which had been neglected in the past. The second tablet, more interestingly, concerned a treaty between the Egyptians and the Hittites on the transfer of the people of the city of Kurustama to Egypt. Though they had sworn an oath by the Storm-god, the Hittites broke their obligations shortly afterwards. Suppiluliuma attacked the country of Amka/Amqa, a territory that belonged to Egypt. The attacks disheartened the Egyptians, and prompted them to request him to send one of his sons to assume kingship. Here the prayer briefly recounts the previously outlined incident: the murder of the prince, the punitive campaign and the outbreak of the epidemic. ${ }^{45}$

Following the discovery of the tablets and the reflection on the recent events, Mursili once again sought divine assistance. The king suspected that the breach of the treaty with the kingdom of Egypt may have been among the reasons for divine wrath and its manifestation, the epidemic. He made an inquiry, as per custom, through an oracle, asking:

Has this matter been brought about by the Storm-god of Hatti because the men of Egypt and the men of Hatti had been put under oath by the Storm-god of Hatti? [...] [T] he men of Hatti themselves suddenly transgressed the word (of the oath), did this become the cause for the anger of the Storm-god of Hatti, my lord? ${ }^{46}$

The answer was affirmative. It should be noted that this treaty is also attested by other contemporary sources, such as the Deeds of Suppiluliuma, ${ }^{47}$ the 'Fifth' Plague Prayer of Mursili ${ }^{48}$ and the treaty of Ramses II of Egypt and Hattusili II I

46 Ibid., 59. The oracular inquiries also confirmed that the neglect of the ritual of the Mala river was among the reasons for the plague. The 'First' Plague Prayer reveals a further reason: the murder of the legitimate heir to the throne, Tudhaliya the Younger. Ibid., 61-64. 
of Hatti on eternal peace and brotherhood (ca 1259 BCE).49 The treaty reached us in a highly fragmentary condition and leaves many questions, including the identities of the contracting parties, unanswered. .0

The 'Second' Plague Prayer contains a detailed account of the measures taken by the king to appease the gods and to persuade them to abate the plague. He openly confessed and assumed responsibility for the sins of his father, removed the causes of the plague, provided restitution for them, offered rituals for the breached treaty to the Storm-god and the other gods and promised to perform the ritual of the Mala river. ${ }^{51}$ The assumption of responsibility is a most important detail, as the king himself was undoubtedly innocent. The transgressions had been committed by his father; he did not commit them. The 'Fifth' Plague Prayer stresses that he respected the textual integrity of the tablet concerning Egypt, held no knowledge of alterations by the preceding kings, only kept the borders that his father left him and took nothing from the borderland. Mursili was still a child when the transgressions were committed, ${ }^{52}$ but he was bound to suffer their consequences and to seek forgiveness for them in accordance with an ancient moral imperative. The 'Second' Plague Prayer makes it abundantly clear: 'So it happens that people always sin. My father sinned as well and he transgressed the word of the Storm-god of Hatti, my lord. But I did not sin in any way. Nevertheless, it so happens that the father's sin comes upon his son, and so the sin of my father came upon me too'.53

In addition to his reparatory and exculpatory measures, the king passionately pleaded his case before the gods, as if in a legal proceeding, ${ }^{54}$ employing

Beckman, Hittite Diplomatic Texts 1999 (n. 21), 97-98. (Translation of the Akkadian text only.)

5o E.g. Zsolt Simon, 'Zur Datierung des Kuruštama-Vertrages', in Kata Endreffy/András Gulyás (eds.), Proceedings of the Fourth Central European Conference of Young Egyptologists (Budapest: Eötvös Loránd University 2007), 373-385; Itamar Singer, 'The Kuruštama Treaty Revisited', in Itamar Singer, The Calm before the Storm: Selected Writings of Itamar Singer on the Late Bronze Age in Anatolia and the Levant (Atlanta: Society of Biblical Literature 2011), 469-483; Dietrich Sürenhagen, 'Forerunners of the Hattusili-Ramesses Treaty', British Museum Studies in Ancient Egypt and Sudan 6 (2006), 59-67, available at http://www.britishmuseum.org/research/publications/online_journals/bmsaes.aspx.

$51 \quad$ Singer, Hittite Prayers 2002 (n. 45), 59.

$5^{2} \quad$ Ibid., $67-68$.

53 Ibid., 59 .

54 The plague prayers are reminiscent of pleadings before a court of law. 'Muršili II's "First" Plague Prayer' (Theo van den Hout trans.), in Mark W. Chavalas (ed.), The Ancient Near East: Historical Sources in Translation (Malden: Blackwell 2006), 260. 
both natural and social analogies. His most impressive argument is based on $1 \mathrm{X}$ the clichéd parallel between the relationship of gods and kings and of lords 2 and servants. The 'Second' Plague Prayer recalls that if a servant commits a sin and confesses it, his lord may do with him whatever he sees fit. However, since the servant confesses his sin, the soul of his lord should be appeased, and he should dispense with the punishment. Mursili openly confessed and assumed responsibility for the sins of his father; therefore, he expected the gods to show forgiveness and abate the epidemic. In order to demonstrate that it was also in their interest to spare the population, the king even exerted subtle pressure on the gods by repeatedly advising them: if the epidemic continued to rage, nobody would remain to offer them bread and libations. Finally, he expressed his readiness to provide further restitution to the gods, they only needed to specify it in a dream. ${ }^{55}$

The epidemic had devastated the region for nearly two decades before it slowly subsided. The plague prayers attest that the calamity had profound effects on several fields of life. For example, the kingdom had to face extreme difficulties in the supply of labour force, the fulfilment of religious duties and the pacification of subordinated territories. Ironically, for all the pain and suffering, the epidemic could not secure lasting respect for the agreement concerned. The tensions between the neighbouring great powers constantly deteriorated and the ensuing military confrontation once again trampled the treaty under foot. Not much later, the two kingdoms fought one of the greatest battles in the history of the ancient Near East at Qadesh/Kadesh (ca 1274 BCE).

The plague prayers of Mursili present the aftermath of the breach of a treaty from the side of the transgressor. Hittite kings sometimes openly blamed their predecessors for their troubles, and these solemn prayers are not devoid of accusations either. However, they provide an unequalled insight into the perception of the nature of responsibility, punishment and restitution. The prayers are based on the assumption that the misconduct of the king may adversely affect the fate of his realm, and the offended gods may easily bring to ruin even the most powerful empires. They also reflect the precept that if the actual transgressor does not survive long enough to make amends, his successor is bound to assume responsibility and seek forgiveness for his sins. But there is always hope for the repentant, as indicated by the very existence of these texts. 3

55 Singer, Hittite Prayers 2002 (n. 45), 60. 
The Hittite kingdom drifted to the brink of collapse by the end of the Bronze Age. The rapid decline of its once powerful western neighbour removed a major obstacle from the path of the insatiable hegemonic ambitions of the kings of Assyria. Following the policy of his formidable predecessors, TukultiNinurta I (ca 1243-1207 BCE) continued to expand the territory of his realm with relentless determination. His most significant military achievement, the conquest and deposal of the reigning king of Kassite Babylonia, was celebrated in a lengthy narrative poem, which reached us in a few fragmentary Middle Assyrian and Neo-Assyrian editions. ${ }^{56}$ Though manifestly biased and highly propagandistic, this epitome of political literature also reveals or reaffirms many important details of our subject.

The Epic of Tukulti-Ninurta revolves around the breach of a treaty. Kashtiliash IV, king of Babylonia (ca 1232-1225 BCE) reportedly turned against his northern neighbour in contravention of an agreement made by one of his predecessors. Treaties between the kings of Assyria and Babylonia had had a rather long history even at that time. ${ }^{57}$ The treaty at the centre of the narrative may have been concluded approximately a generation prior to the events depicted in the epic by Adad-nirari I, king of Assyria (ca 1295-1263 BCE) and Kadashman-Turgu, king of Babylonia (ca 1281-1264 BCE). ${ }^{58}$ Fragments of this particular treaty have apparently been found, but the available text excludes the possibility of a meaningful translation. ${ }^{59}$ Nevertheless, the epic suggests that the agreement probably provided for the delimitation of borders and the renunciation of force. ${ }^{60}$

The Babylonian encroachment and plundering had extremely serious consequences. Tukulti-Ninurta placed the sealed tablet of the treaty before Shamash, the divine witness and guarantor of the treaty, represented perhaps by his altar, statue or symbol, and brought his complaint to him (and to the other gods). The king emphasized his innocence and obedience, reminded

56 Peter B. Machinist, The Epic of Tukulti-Ninurta I: A Study in Middle Assyrian Literature (PhD dissertation, Yale University 1978), 17.

57 Glassner, Mesopotamian Chronicles 2004 (n. 10), 176-179. See also A. Kirk Grayson, Assyrian and Babylonian Chronicles (Winona Lake: Eisenbrauns 2000).

58 Trevor Bryce, Letters of the Great Kings of the Ancient Near East: The Royal Correspondence of the Late Bronze Age (London: Routledge 2003), 11.

59 A. Kirk Grayson, Assyrian Royal Inscriptions, vol. 1: From the Beginning to Ashur-resha-ishi I (Wiesbaden: Otto Harrassowitz 1972), 78.

6o Peter Machinist, 'Literature as Politics: The Tukulti-Ninurta Epic and the Bible', The Catholic Biblical Quarterly 38(4) (1976), 455-482, 457-458. 
the deity of the agreement made by his predecessor and passionately charged $1 \mathrm{X}$ his neighbour with transgression and disobedience. He requested the deity to 2 adjudicate his claim by helping the compliant to triumph over the transgressor. The ensuing military confrontation was thus transformed into a quasi-ordeal:

O Shamash, lord [...], I abided by (?) your oath, I feared your greatness. 6 He who has not [...] transgressed before your [...], but I kept your 7 command.

When our ancestors made a pact [bef] ore your divinity, they established an oath between them, they invoked your greatness. $\quad 10$ $[\ldots]$

Why has the king of the Kassites long frustrated your plan and your command?

He did not fe[ar] your oath, he transgressed your judgment,

His filled up the measure of his sins before you. O Shamash, judge me!

[But as for the one wh] o committed no offense against the king of the

$[\ldots]$ Grant victory $[. .$.$] to the one who keeps the oath.$

[As for the one who does not obey] your instruction,

Having made a formal plea to the god of the oath, the enraged king addressed his treacherous neighbour in an exchange of messages. He brought to mind the sins of his counterpart, raised the tablet of the treaty, read it out to the deity and reasserted his own innocence. Then he stated that the dispute could only be resolved by a contest of arms in which the transgressor would face certain defeat. Hence peace and good relations could not be restored without rise up' ${ }^{62}$ It has been pointed out that these messages exhibit structural and thematic similarities to the preceding plea to the god of the oath and to several pieces of contemporary diplomatic correspondence. ${ }^{63}$ Kashtiliash suddenly

$61 \quad$ 'The Tukulti-Ninurta I Epic' (Christopher Morgan trans.), in Chavalas, The Ancient Near East 2006 (n. 54), 148.

63 Machinist, The Epic of Tukulti-Ninurta I 1978 (n. 56), 251, 253-254. 40X 
before Shamash, [my] guilt [is great.] ${ }^{64}$ Though he confessed his sin, he could not redeem himself. The prospect of divine punishment drove him to despair; terrible fear and anxiety overwhelmed him. His wickedness stood in stark contrast to the rectitude of his adversary. The resentful gods had abandoned him long ago, leaving him deprived of favourable signs and tormented by nightmares. He anticipated that the retribution would be catastrophic to himself, his land and his people alike - and he was not mistaken. ${ }^{65}$

The kingdoms clashed as foreseen, but the outcome was never in doubt. With the direct support of the gods, Tukulti-Ninurta smashed all opposition in his ferocious campaigns: he captured and fettered the king of Babylonia, demolished the fortifications of the enemy capital, massacred the inhabitants and seized the treasures as spoils of war. His triumphant armies, in an act of enormous humiliation and sacrilege, even pillaged the temple of Esagila and abducted the statue of the local patron deity, Marduk. ${ }^{66}$ Tukulti-Ninurta proudly added to his royal titulary the title 'king of Karduniash, king of Sumer and Akkad, king of Sippar and Babylon, king of Tilmun and Meluhha' 67 and exercised control over the conquered territories for years. However, he could not escape his destiny either; his life and reign were ended by a rebellion. The events were carefully recorded in the chronicles: 'During the lifetime of TukultīNinurta, Aššur-nādin-apli, his son, took the throne. He reigned 3 years', ${ }^{68}$ and also: '[...] Aššur-nāṣir-apli, his son, and the Assyrian officials revolted against Tukultî-Ninurta [...], deposed him from his throne, locked him in a room in Kār-Tukultī-Ninurta, and put him to death'. ${ }^{69}$

The reign of Ashur-nadin-apli/Ashur-nasir-apli (ca 1207-1204 BCE) brought a period of prolonged domestic political turmoil for the kingdom of Assyria. The Babylonians cast off the yoke of their oppressors at the first opportunity, but the Kassite dynasty could not retain power for long after the restoration. In only a few decades, it finally collapsed under the attacks of its south-eastern neighbour, Elam.

64 'The Tukulti-Ninurta I Epic' 2006 (n. 61), 149.

65 Ibid., 149-150.

66 Glassner, Mesopotamian Chronicles 2004 (n. 10), 281.

67 J. Margaret Munn-Rankin, 'Assyrian Military Power 1300-1200 B.C.', in Iorwerth E.S. Edwards et al. (eds.), The Cambridge Ancient History, vol. 2, pt. 2: History of the Middle East and the Aegean Region c. 1380-1000 B.C. (Cambridge: Cambridge University Press, third edition 2006), 287-288.

68 Glassner, Mesopotamian Chronicles 2004 (n. 10), 143.

69 Ibid., 281. Kar-Tukulti-Ninurta bore the name of its founder. The city served for a while as a cult centre/capital of the kingdom. 
The Epic of Tukulti-Ninurta presents the breach of a treaty from both perspectives, but in a blatantly partial manner. In spite of the total absence of balance and objectivity, this enthralling story ranks among the most useful sources due to its lengthy and detailed treatment of the nature and sequence of procedural measures taken by the injured party in the wake of the transgression. The epic also confirms that the breach of a treaty is a heinous offence against both men and gods, the gravity of which is reflected by the harshness of punishment. Here the transgressor cannot hope for mercy: abandoned by his gods and deprived of the strength of character, he must suffer the consequences of his misconduct. His prospering kingdom falls with him in the ordeal of battle.

The Old Testament, along with its textual basis, the Hebrew Bible, is a unique 15 source for the study of the breach of treaties. The Book of Joshua and the Second Book of Samuel, though the historicity of their narratives is under constant survey, particularly broaden our horizons. Many details of the story are common knowledge. Moses brought his people to the edge of Canaan, but he could not set foot on its ground. ${ }^{70}$ Fulfilling the command of the Lord, he entrusted his faithful and capable aide, Joshua, son of Nun, to lead the conquest and settlement of the land 'flowing with milk and honey' and to divide their divinely promised 'inheritance' among the tribes. The Lord reaffirmed the mandate, pledged his help and required a strict observance of the Book of the Law. ${ }^{71}$ These rules of conduct also explicitly laid down the expected behaviour during the conquest. Distant cities and peoples were to be offered peace at first. The acceptance of the offer meant that such peoples were placed under tribute and subjected to forced labour and servitude. The refusal of subjugation and the commencement of hostilities opened the way for destruction and plundering. Nearby cities and peoples, the inhabitants of Canaan, had to be treated in an entirely different manner. The Israelites had to completely destroy them to prevent conversion to the worship of local deities and the perpetration of sins against the Lord..$^{72}$ The Old Testament repeatedly emphasizes that the conclusion of treaties with such peoples was also prohibited..$^{73}$ 16 17 18 19 
The Book of Joshua describes taking possession of the land as a single sweeping campaign directly supported by the Lord. ${ }^{74}$ The Israelites, after crossing the Jordan river, rapidly defeated Jericho and Ai and reduced both cities to rubble. ${ }^{75}$ Having heard of the events, the Gibeonites were desperate to avoid elimination at any cost, therefore, they resorted to an elaborately planned deception to save their lives. They dispatched a delegation dressed in shabby robes and patched sandals on donkeys carrying worn sacks, cracked wineskins and dry and mouldy bread to create the impression as if the envoys had been travelling from a great distance. Perfectly aware of the expected behaviour of the Israelites towards distant cities and peoples, the Gibeonite envoys introduced themselves as representatives of a faraway land and offered subjugation by means of a treaty: 'We have come from a distant country; make a treaty with us. $[\ldots]$ We are your servants. ${ }^{76}$ Notwithstanding their misgivings, the Israelites accepted the offer without seeking advice from the Lord: 'Then Joshua made a treaty of peace with them to let them live, and the leaders of the assembly ratified it by oath. ${ }^{77}$ The treaty must have been a non-parity treaty and probably contained the usual elements thereof, including the subjugation, loyalty and obedience of the inferior party, the establishment of peaceful relations between the parties, the protection of the inferior party and the provision of military assistance against the enemy. ${ }^{78}$

The deception was exposed shortly afterwards. The Israelites were abashed to learn that the Gibeonites were actually living nearby and they hurriedly marched up to their cities-Gibeon, Kephirah, Beeroth and Kiriath Jearim. However, they could not launch an attack and eliminate them without transgressing the oath sworn by the Lord. ${ }^{79}$ The validity of the treaty was apparently

74 Evidence suggests that the complex and long process of settlement must have taken place in a rather different manner. William G. Dever, 'Israel, History of: Archaeology and the Israelite “Conquest”'; and Robert G. Boling, 'Joshua, Book of', in Freedman, The Anchor Bible Dictionary, vol. 31992 (n. 2), 545-558, 1002-1015.

75 Josh. 5:13, 6, 8:1-29.

76 Ibid., 9:1-13.

77 Ibid., 9:14-15. The Israelites had to request divine guidance in certain situations rather than relying on their own understanding. The significance of this requirement is also shown by the narrative, which explicitly recalls the failure to seek advice from the Lord. See also Num. 27:21; Prov. 3:5-6.

78 F. Charles Fensham, 'The Treaty between Israel and the Gibeonites', The Biblical Archaeologist 27(3) (1964), 96-100, 97-99; Jehoshua M. Grintz, 'The Treaty of Joshua with the Gibeonites', Journal of the American Oriental Society 86(2) (1966), 113-126, 115, 123-125. 79 Josh. 9:16-19. 
unaffected by the fraudulent conduct of the other party. ${ }^{80}$ The Israelites $1 \mathrm{X}$ expressed a great deal of indignation at this state of affairs until Joshua and their leaders proposed and implemented a serviceable solution. The Gibeonites were eventually allowed to live, but as a punishment for their deception, they were bound to hew wood and carry water for the assembly and to act as servants of the altar of the Lord. ${ }^{81}$ The Book of Joshua also reveals that the treaty compliance of the Israelites was put to the test again, when a coalition of five local kings attacked the Gibeonites. Although they were skilled fighters, they had to request urgent military assistance from Joshua. The Israelites marched to the rescue of their allies, and with the direct support of the Lord, triumphed over the enemy in an epic battle in which even the sun stood still, and the moon stopped'. ${ }^{82}$

The Israelites took possession of the land as envisaged, but the attacks by neighbouring peoples continued. The incessant hostilities brought about a fundamental and gradual shift in the political organization of the tribes that initially produced the emergence of judges, and ultimately resulted in the establishment of monarchy. This latter development was not without reluctance; the traditional idea of theocracy recognized only one true sovereign, the Lord. The Second Book of Samuel recounts that during the reign of David, king of Israel and Judah (ca 1010/1002-970 BCE), a severe famine struck the land for three successive years. Upon his inquiry, the Lord revealed the reason for the calamity to the king: his father-in-law and predecessor, Saul (ca 1050-1010 BCE), blinded by his zeal for the kingdom, made an attempt to eliminate the Gibeonites. ${ }^{83}$ The massacre was clearly in contravention of the treaty that had been concluded in the time of Joshua, and the famine was a consequence of the transgression. David summoned the Gibeonites and asked them to determine the nature of the reparation. They requested blood vengeance: 'As for the man who destroyed us and plotted against us so that we have been decimated and have no place anywhere in Israel, let seven of his

$80 \quad$ Sulyok, 'Treaties, Origin' 2015 (n. 2), para. 31.

81 Josh. 9:20-27.

82 Ibid., 10:1-15.

832 Sam. 21:1. There is a remarkable parallel in the perception of the causality link between the breach of a treaty and a national catastrophe in the plague prayers of Mursili and in the Old Testament. Abraham Malamat, 'Doctrines of Causality in Hittite and Biblical Historiography: A Parallel', Vetus Testamentum 5(1) (1955), 1-12. 
male descendants be given to us to be killed and their bodies exposed before the Lord at Gibeah of Saul-the Lord's chosen one.' ${ }^{84}$

The king granted their request and handed over seven male descendants of his predecessor, who were all executed in the first days of harvest. However, David spared the life of Mephibosheth, the son of his former friend, Jonathan, out of respect for the oaths that they had previously exchanged. In stark contrast to local customs, ${ }^{85}$ the Gibeonites left the bodies exposed on a hill ${ }^{86}$ - a procedure that resembles Deuteronomic and treaty curses threatening transgressors with being devoured by various animals. ${ }^{87}$ Rizpah, the mother of two of the executed descendants of Saul, did not allow this to happen: she tirelessly chased away the birds and the wild animals throughout the season of harvest until it started to rain. When David heard of this, he commanded that the remains of Saul and Jonathan, both of whom had perished earlier during a battle against the Philistines, and their recently executed kinsmen be laid to rest. The Second Book of Samuel suggests that once the Gibeonites had been avenged, the Lord showed forgiveness and the famine immediately ended: 'After that, God answered prayer in behalf of the land: 88

The Old Testament reaffirms that the perception of responsibility, punishment and restitution was remarkably similar among peoples of the ancient Near East. The Book of Joshua and the Second Book of Samuel present the conclusion and breach of a treaty from the side of the transgressor. The story contains several familiar elements: although here the divine punishment is not inflicted instantly, the misconduct of the king eventually affects the fate of his realm and the reconciliation becomes the task of his successor. Forgiveness can only be obtained at a great cost; the descendants of the transgressor must pay with their lives for his actions. The fact that the breached treaty was concluded as a result of fraud has no relevance, as the Lord requires the keeping of an oath 'even when it hurts'.89

84 2 Sam. 21:2-6.

85 Deut. 21:22-23.

86 2 Sam. 21:6-9.

87 Deut. 28:26. Compare 1 Sam. 17:43-44. See also the treaty of Esarhaddon of Assyria and Baal of Tyre and Esarhaddon's succession treaty/vassal treaties of Esarhaddon (7th century BCE). Simo Parpola/Kazuko Watanabe (eds.), Neo-Assyrian Treaties and Loyalty Oaths (Helsinki: Helsinki University Press 1988), 27, 46, 48, 49, 51, 53.

88 2 Sam. 21:10-14.

89 Ps. $15: 4$. 
The preceding survey of selected sources arguably permits the identification of recurring motifs and the formulation of a few general observations. It may seem like a bold endeavour to draw conclusions from a handful of fragmentary ancient texts, but in this particular case the appearances are deceptive and the reservations are not warranted. It should not be left unnoticed that our selection of sources transcends huge geographical and temporal dimensions and displays a remarkable diversity. More specifically, the surveyed texts come from different regions and peoples, reflect different periods and circumstances, represent different cultural traditions and literary genres, address different recipients and audiences and serve different purposes, including moral education, legal reasoning, religious supplication and political propaganda. Besides, they feature both parity and non-parity treaties. These properties of our selection render the drawing of tentative conclusions possible.

The breach of treaties, as has been premised, must have been a rather persistent problem, which could be effectively precluded by neither terrifying conditional maledictions nor other treaty guarantees. The relative abundance and diversity of sources in which the subject came up also strengthen the impression that such occurrences were regarded as events of utmost importance in the ancient Near East. ${ }^{90}$ Furthermore, for all their divergence in terms of contents and emphases, our sources persuasively attest the existence of deeply rooted shared values and analogous practices as far as the breaking of treaty obligations is concerned. ${ }^{91}$ Even though the majority of the surveyed texts are biased to some extent, it may be reasonably stated that the perception of the breach of treaties was extremely and uniformly negative. This attitude was a result of a number of factors and manifested itself in a number of ways.

The breach of treaties was perceived to simultaneously disrupt both the divine and human orders. This dichotomy can be attributed to the fact that the oath by the gods was an essential constituent of contemporary treaties. The deities thus invoked were witnesses and guarantors of these agreements

$90 \quad$ Sulyok, 'Treaties, Origin' 2015 (n. 2), para. 36.

91 These shared values and analogous practices are also attested by the relevant terminology and diplomatic correspondence. E.g. F. Charles Fensham, 'Malediction and Benediction in Ancient Near Eastern Vassal-Treaties and the Old Testament', Zeitschrift für die Alttestamentliche Wissenschaft 74(1) (1962), 1-9, 3-5; Machinist, The Epic of TukultiNinurta I 1978 (n. 56), 252-256; Moshe Weinfeld, 'Covenant Terminology in the Ancient Near East and Its Influence on the West', Journal of the American Oriental Society 93(2) (1973), 190-199, 197. 
at the same time. ${ }^{92}$ Hence the breach of a treaty injured not only the other party, but also the gods of the oath. ${ }^{93}$ The supremacy of the divine order and the direct affectedness of the gods, coupled with the absence of appropriate 'earthly' dispute-settlement mechanisms, ${ }^{94}$ entailed that supernatural powers were held to play a fundamental role in the process. The injured party was, as a general rule, expected to issue a formal appeal to the gods, present the circumstances of the transgression, recite the contents of the treaty, demonstrate his obedience, and request the adjudication of his claim and the punishment of the transgressor. The fulfilment of his request was far from being automatic or guaranteed; the injured party had to persuade the deities to secure a favourable decision. ${ }^{95}$

The breach of a treaty may also have been invoked as a ground for termination. ${ }^{96}$ This appears to be the outcome of a relatively long development. The peculiarities of the formulation and conclusion of certain treaties are held to have precluded reciprocity arguments, including claims based on any distant predecessor of the inadimplenti non est adimplendum principle, in the first half of the second millennium все. ${ }^{97}$ Indeed, Old Babylonian period treaties were concluded, at least in part, in writing by parallel unilateral documents drawn up by one party for the other. Each document set forth the obligations of the other party and was transferred to him for acceptance. Located at a distance from each other, the parties could hardly take the oaths by the gods simultaneously; they had to make their pledges independently. This method of treaty-making may actually have had the effect that the fulfilment of obligations by one party was not conditioned on the treaty compliance of his partner. ${ }^{98}$ However, the emergence of more advanced treaty practices, such as the spelling out of obligations of both parties in each treaty document, meant that by the second

Donald L. Magnetti, 'The Function of the Oath in the Ancient Near Eastern International Treaty', American Journal of International Law 72(4) (1978), 815-829, 815, 824; Karl-Heinz Ziegler, 'Conclusion and Publication of International Treaties in Antiquity', Israel Law Review 29(1)-(2) (1995), 233-249, 234.

93 J. Margaret Munn-Rankin, 'Diplomacy in Western Asia in the Early Second Millennium B.C., Iraq 18(1) (1956), 68-110, 89.

94 Magnetti, 'The Function of the Oath' 1978 (n. 92), 815, 824. See also Altman, Tracing the Earliest Recorded Concepts 2012 (n. 2), 12-13.

95 Amnon Altman, "The Role of the "Historical Prologue" in the Hittite Vassal Treaties: An Early Experiment in Securing Treaty Compliance', Journal of the History of International Law 6(1) (2004), 43-63, 50-53.

96 Sulyok, 'Treaties, Origin' 2015 (n. 2), para. 35.

97 Kolb, The Law of Treaties 2016 (n. 3), 2, 13. 
half of the second millennium $\mathrm{BCE}$, the injured party had become entitled to declare himself discharged of his obligations upon the breach of a treaty. This option may have been available regardless of the nature and importance of the infringed provision. ${ }^{99}$

The outline of the procedure above is highly presumptive, and it requires a few supplementary remarks. Some of our sources suggest that the injured party may have chosen not to issue a formal appeal to the gods in the wake of every single transgression, although it may well be that the relevant references were simply omitted or are missing from the available texts. Nevertheless, it must have been a matter of course for peoples of old that the gods of the oath, acting in their capacity as guarantors of the treaty, were able to take action without human initiative, of their own accord. In any event, if the gods fulfilled the request of the injured party and avenged the transgression, the divine punishment could be either direct or indirect. Direct forms of punishment were allegedly inflicted by the gods themselves (e.g., epidemic, famine). Indirect forms of punishment, on the other hand, were inflicted by the injured party employed as an instrument of divine wrath (e.g., mutilation, defeat, captivity, downfall). ${ }^{100}$ It should be added that many treaty curses were carefully formulated to target, apart from the contracting parties, the broadest possible group of persons and objects. Our sources confirm the firm belief that the divine punishment could also affect the family, descendants, possessions, subjects and land of the transgressor. Entire empires could decline or collapse in accordance with this 'primeval notion of collective guilt'. ${ }^{101}$ The anticipated dire consequences prompted parties to go to great lengths to dispel the suspicion of transgression as soon as it arose. ${ }^{102}$ They had every reason to do so, because forgiveness was not granted easily. If the transgressor had the fortune to survive the retribution at all, he could only entertain the hope of redeeming himself after prolonged suffering, sincere repentance, generous offerings and ample restitution. ${ }^{103}$ The same holds true for cases in which the responsibility was shifted to a person other than the actual transgressor.

99 Ibid., 117, n. 129 and 122.

100 Sulyok, 'Treaties, Origin' 2015 (n. 2), paras. 37-38.

101 Ibid. para. 38.

See the letter of Ramses II of Egypt to Kupanta-Kurunta of Mira-Kuwaliya (13th century BCE), in which the pharaoh felt the need to explain to a lesser ruler that, contrary to the rumours, he had not breached the treaty that he had concluded with Hattusili III of Hatti. Beckman, Hittite Diplomatic Texts 1999 (n. 21), 130-131. 
The negative perception of the breach of treaties also became evident in the portrayal of the transgressor. More often than not, the transgressor is portrayed as a despicable character, who flouts the oath by the gods, treats the other party with contempt, neglects the possible consequences and relentlessly commits his heinous offence. His personality and conduct are deemed so revolting that he can no longer enjoy divine support; the gods abandon him. Some of our sources even deprive this 'villain' of the strength of character: near the climax of the story, when he belatedly realizes what he has done and what lies ahead of him, he spectacularly collapses and pathetically begs for mercy and/or awaits the retribution trembling in fear. ${ }^{104}$ His character looks particularly corrupt in the light of the personal and moral integrity of the injured party. However, the portrayal and contrasting of the opposing parties were not the only methods to expose the gravity of the breach of treaties. Lively descriptions of the harshness of punishment and the hardships of redemption may have had a similar function. It should be emphasized once again that these conclusions are tentative. Until archaeologists and historians provide further evidence, scholars of international law probably have to content themselves with these small pieces of a sizeable and fascinating puzzle.

104 Ibid. 